\title{
相互行為実践としての対話ロボットに対する態度 Attitude towards Dialogue Robot as Interactional Practice
}

\author{
小室允人 \\ Masato Komuro \\ 千葉大学大学院 人文社会科学研究科 \\ Graduate School of Humanities and Social Sciences, Chiba University \\ afpa2850@chiba-u.jp \\ 船越 孝太郎 \\ 東京工業大学 科学技術創成研究院 \\ Kotaro Funakoshi \\ Institute of Innovative Research, Tokyo Institute of Technology
}

Keywords: Conversation Analysis, Ethnomethodology, Turing Test, Human-Likeness, Human-Robot Interaction.

\section{Summary}

The questions "How human-like is this dialogue robot?" and "How natural was the conversation with this dialogue robot?" are major concerns for dialogue robot researchers and developers. However, they have overlooked the way that unique conversational structures exist in actual conversations between humans and dialogue robots, which are different from those between humans. In this paper, we focus on the repetition of the user's own speech, and the user's commenting in the absence of a robot's response, in a conversation with a dialogue robot. These phenomena are unique to conversations with dialogue robots. When the user's speech is not inputted into dialogue robots, users often repeat their own speech. In addition, when the repeated speech is also not inputted to the dialogue robot, users often comment on the absence of response from the robot by giving reasons why the robot does not respond. These phenomena are organized in order, which means the repetition is performed firstly, and if the repeated speech is not inputted, then secondly, users will comment on the absence of response from the robot. We analyze these situations using conversation analysis methods, and discuss how these phenomena are organized in order, and how these phenomena are unique to conversations with dialogue robots. In the last part of the paper, we reconsider the "human-likeness" of dialogue robots.

\section{1. はじめに}

人との対話を目的とした対話ロボットの開発におい て，「この対話ロボットはどのくらい人らしいのか」, も しくは「どのくらい自然な会話であったか」という問い は, 対話ロボット研究者・開発者にとって重要な関心事 である，そもそも対話ロボットは，人を模したものであ る以上，これは当然の関心事であるだろう。人工知能研 究の初期に提案されたチューリングテスト[Turing 50]も, 当該の人工知能が，どのくらい「人らしい」のかという ことの評価法として捉えられてきた[東中 14$]^{* 1}$.

また，対話ロボットがどのくらい「人らしい」のかと いうことは，単に SF 的観点からの関心事ということで はなく，ユーザエクスペリエンスという実用性からの関 心事であるとも言える. 例えば神田 [神田 13] は, ロボ ットに「人らしさ」を感じることで,「誰かと関わりたい」 という気持ちに似た「ロボットと関わりたい」という動 機づけがユーザに起きることを，事例を通じて紹介して いる.

\footnotetext{
${ }^{* 1}$ チューリングテストの本来の目的は，機械に人のふりをし て会話をさせる（機械だと見破られないように試験者からの質 問に答えさせる）ことで，「機械は思考できるといえるか」と いう問いに, アンケート調查などの主観評定に依らずに，答え を出すことであるが，人らしく振る舞わなければそれによって
}

また近年では，雑談のような対話自体を目的とする非 タスク指向型対話も特に注目され，不自然な会話になら ないよう対話の破綻をどのように検出するべきか[角森 20]といった議論も活発である.

このような関心のもと，これまで対話ロボット開発の 現場では，様々な方法によって対話ロボットに「人らし さ」を実装し，できるだけ人との対話に近い「自然な会 話」を実現させようという試みがなされてきた。例えば ロボットの外見を人に近づけることによって，人らしい 存在感を表出できることは良く知られている[坂本 07]. 外見以外の研究例では，対話システムに間投詞を発話さ せることで，より「自然な会話」の生成が可能であった り，ロボットに良い印象を持たせたりすることがわかっ ている [伊藤 99, 志和 09] .

以上のように，対話ロボットに「人らしさ」や「自然 な会話」をどのように実装するのかという研究は多岐に わたる.一方で, 当該の対話ロボットの「人らしさ」や, 対話ロボットとの発話でのやり取りが「自然な会話」で

機械であると見破られてしまうため，応答の正確さや，その速 さといった「話し方」まで含め,「人間らしいか」という問い もテストに織り込まれていることになる. 
あったかどうかは, 調査協力者の主観評定による評価 (インタビュー調査やアンケート調査等) に頼るのが一 般的である．例えば，日本においては上出ら [上出 16] が, 欧米におけるロボットの擬人化尺度を発展させ, 擬 人化の程度を測定する心理学的評価手法を確立している. 上出らの研究は, 8 種類のロボットの刺激写真を用意し, 調査対象者に評価してもらうという, ロボットの外見か ら擬人化の程度を測るものであるが，人とロボットのイ ンタラクションに焦点をおいた他の研究においても,「こ のロボットは人らしかったか」,「ロボットとの会話は自 然であったか」等の質問を項目に入れた心理学的評価法 は，ごく一般的である.

しかし, 主観評定による心理学的評価法は, ユーザの, 対話ロボットへの印象が端的にわかるという利点がある 一方, 対話ロボットの「人らしさ」が, 実際の対話ロボ ットとの会話において, どのような発話によって具体化 しているのかという, 対話ロボットー人間における会話之 $\dot{\sigma} \dot{も} \dot{\sigma} \dot{\sigma}$ 構造的な諸特徵*2は，その自明性ゆえに調査協 力者ら自身にも気づかれにくく，したがって主観評定に よる評価が一般的なこれまでの研究においては, 研究対 象として見落とされがちであった.

最も, 日常会話の構造の諸特徵を，対話ロボット開発 者が，これまで全く念頭に置いていなかったということ はない.むしろ対話口ボットの開発者らは, 人文科学系 の研究結果としての人一人間の会話における構造の諸特 徵を, 積極的に対話ロボットの開発デザインとして取り 入れてきた[山崎 11]. しかし, 開発された対話ロボット の評価という段階になると, その評価はインタビュー調 查や, アンケート調査にまかされ, 肝心の対話ロボット と人との対話の具体的な会話構造の諸特徵は, 見過ごさ れてきたと言える.

しかしながら，対話ロボットー人閒の会話に特有の諸 特徴を記述できるのならば, 人一人間の会話と, 対話ロボ ットー人間の会話との違いの解明に, 新たな知見を提供で きよう.

本稿では, 実際の対話ロボットと人との会話を録画し た動画データを, 会話分析と呼ばれる手法によって検討 することで, 対話ロボットー人間の会話に特有の会話構造 を明らかにしていく.また, 分析によって得られた会話 構造を通じて, 対話ロボットとの会話がユーザらにどの ように理解され, 経験されているのかを考察する.

\section{2. 前提的議論: 魂に対する態度}

本稿の主旨に向かう前に, そもそも「人らしさ」を認 めるということは，具体的にはどのようなことなのかと

\footnotetext{
*2 例えば日常的な場面においては「質問」と「答え」は発話 連鎖として，ペアで産出されることがよく知られている。しか し，授業などに代表される制度的な場面では「質問」と「答 え」は十全なぺアではない. 教師からの「質問」に対して生徒
}

いう点に関して，若干の前提的議論が必要だろう。例え ば，私たちは普段から，誰かに対して「人らしさ」を認 めているのだろうか。私たちは，まさに人である他者に 対して, 普段どのような態度を向けているのだろうか.

ここでの「態度」という語は, Wittgenstein [Wittgenstein 58] の「魂に対する態度」に関する議論を 倣ってのものである. Wittgenstein の議論自体, 大変に 難解であり，また彼のスタイルがわかりやすい説明を省 くというものであるがゆえに，その解釈も多岐にわたっ ている、しかし, あえてここでは, 彼の議論から触発さ れた一つの解釈の提案を試みたい.

後期 Wittgenstein の代表的な著書である『哲学探求』 の第二部において, Wittgenstein は「彼は自動機械では ない」という言明の無意味さについて説明している。私 たちは通常, 誰かを「自動機械ではない」などと思うこ とはない. かといって, 誰かを「自動機械である」と考 えているわけでは勿論ない.つまり, 誰かが「自動機械」 であるかどうかということは，通常私たちが他者を理解 するうえで, 常に「レリヴァント (relevant)」であるわ けではない.

この説明に続いて Wittgenstein が述べていることを 引用しよう

彼に対する私の態度は, 魂 (Seele) に対する態度であ る、しかし私は，彼は魂を持っている，という意見を持 っているのではない.

p.12 [黒崎訳]

Wittgenstein は，私たちは誰かを見て「彼は魂を持って いる」という意見を持つわけではないと言う。つまり， 日常的な活動において, 誰かが自動機械であるかどうか が私たちにとって常にレリヴァントなわけではないのと 同様に，誰かが「魂」を持った人であるかどうかという ことも私たちにとって常にレリヴァントであるわけでは ない. それでは, 誰かを「魂を持った人間」として見做 すということは，具体的にはどのようなことなのだろう か. 例えば丸田 [丸田 10] は,「魂に対する態度」につい て, 次のように述べている.

すると次に，魂に対する態度を人に対してとることが， より具体的にはよ゙ういうことかを考えねばなるまい，そ してそれは例えば，怪我をして泣いている子どもを目前 にして，「転倒したことと，血液が表皮に滲んだことと， けたたましい声の閒には、いかなる因果関係があるのか」 なよ゙と異星人のように㫢きつつ，熱心に観察を始めたり するのではない，ということである。あるいは「彼が本

が「答え」たとき, 生徒の「答え」を, 教師は「評価」しなけ ればならない。このように, 日常的会話場面, 制度的会話場面 にはそれぞれの会話に特有の構造的諸特徵が観察される. 
当に痛いのかは，他人の心は視けない以上，知るよしも ない，そもそも彼に心があるのかさえ分からない」とう そぶくことでもない，魂に対する態度をとるということ は，そうでなく，「ああ，痛そうだ」と思い，手当てをす る，いたわる，慰める，ということなのである，あるい は逆に，「それくらいどうした。意気地なしめ」と，突き 放すこと，叱咤すること，励ますこと，である。

つまり，「魂に対する態度」とは，他者が魂を持つ人間 であることが自明の前提のときに，私たちが他者に対し て取りうる，ふさわしい相互行為実践亡しての「態度」 なのである。

以上の Wittgenstein の議論は, 対話ロボットに「人らし さ」を認めることとは，具体的にどのようなことなのか を考えるにあたって示唆的である. 寸なわち, 私たちが ロボットに出会うとき，眼前のロボットに「人らしさ」 を感じるかどうかということ以前に, そ市吕ボットを「人

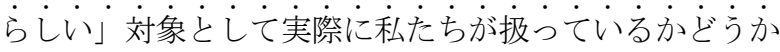
という, 相互行為実践の水準における問題提起となろう. 本稿ではこの問題に取り組むために，先に述べたよう に，会話分析と呼ばれる手法を用いる．会話分析は，人 一人間の会話における相互行為実践の解明をその役割と して担ってきた.よって, 対話ロボットー人間の会話にお ける相互行為実践の解明という, 本研究の目的に合致し たアプローチであると言える．次章では会話分析の基本 的な考え方と，本研究での方針を紹介寸る.

\section{3. 会話分析の考え方と本研究の方針}

会話分析とは, 1960 年代後半に, Garfinkel と Sacksに よって創始されたエスノメソドロジーから発展した，社 会学の領域における会話の研究を専門とする一分野であ る. 会話分析は特に, 自然会話における会話の参与者ら の相互行為実践と，それが織りなす会話構造を発見する ことを得意としてきた。代表的な研究成果としては, Sacks らによる, 会話分析の記念碑的な論文でもある「順 番交替論文」 [Sacks 74a] がよく知られている.この論文 にて Sacks らは，日常会話における発言順番がどのよう に交替するのかという会話構造を明らかにしている。ま た，会話分析が分析の対象とするものは日常的な会話場 面にとどまらない，例えば Mehan [Mehan 79] は，会話分 析の手法を取り込み, 日常場面における発話連鎖構造と, 学校などの授業場面における発話連鎖構造との間に違い があることを報告している，他にも，会話の構造を明ら かにしてきた会話分析の研究は，枚挙に暇がない. よっ て, 対話ロボットー人間に特有の会話構造を明らかにしよ うとする本稿の目的に, 会話分析の手法を用いることは, 適切であると考えられる。

本稿では，4 つの会話断片に，会話分析の手法を用い
た分析を加えることで, 対話ロボットー人間の会話に特有 の構造的な諸特徵を明らかにしていく. 一方で, 本稿で の検討に，定量的な分析は行わない．もちろん，検討の 対象である対話ロボットー人間の会話に特有の構造は, 本 研究で用いたデータ内において, たびたび観察されたも のではあるが，しかし，㛜密な定量分析などは施されて いない. また，後の分析部においては，実験参加者らが 対話ロボットとの会話において成し遂げていることが

「行為」として分析されているが, 実験参加者らが本稿 で主張していることを実際に行っていたのかどうかを， 本人へのインタビューなどによって確かめるということ もしていない.

このような本稿での研究方針のもとでは，その研究結 果の妥当性や一般性が疑わしいという懸念は, 当然あり 得るように思う。よって本章では，多少遠回りに感じら れるかもしれないが，定量分析とインタビュー調査を行 わない理由について，幾分丁寧に説明しておく.

\section{1 なぜ定量分析をしないのか}

本稿の目的の一つは，対話ロボットー人間の会話に特 有の会話構造を見出すことであるが，これは単にその構 造が多く観察できるというだけではない。むしろ本稿が 強調するところは, 対話ロボットー人間の会話に特有の構 造は，規範的な秩序のもとに組織された構造であること を明らかにするところにある。そして，会話分析創設期 の立役者の一人である Schegloff [Schegloff 68] が，初期 の論文にて詳しく述べていたように，規範的な秩序は数 を数えることで証拠立てられるというものではない.

ここで理解の手助けのために，一つの例を挙げたい. 私たちは「赤信号は止まれ，青信号は進め」ということ を知っている，実際によく私たちは，横断歩道を渡る際 に，赤信号では立ち止まるし，そのあとに信号が青に転 じれば再び歩きだすだろう。どうやら信号に関する私た ちの行動には,「赤信号は止まれ, 青信号は進め」という 命題で表すことができるような，パターンとしての秩序 がありそうだ.

さて, とある横断歩道では, 人々は赤信号であっても よく横断歩道を渡っているのが観察されたとしよう。そ の横断歩道での赤信号を渡る人と, 青信号を渡る人の数 を数えてみると，ほぼ同数である．彼らにとって眼前の 横断歩道を渡るのか渡らないのかという判断は，信号機 が赤か青かということよりは，実際に車が近づいている かどうかということにむしろ関係がありそうだ。それで は，この横断歩道においては「赤信号は止まれ，青信号 は進め」という秩序などない, となるのかというとそう ではない，私たちは，この横断歩道において赤信号にも かかわらず横断歩道を渡る人を、「信号無視をしている人 として理解することができる．また，信号を無視してい る当の本人も，自身の振る舞いを信号無視だと理解して 
いるはずだと, 期待することができる.つまり私たちは, 信号機が赤か青かということと, 横断歩道を渡るという 行為とを結びつけて理解することができている.そして， 赤信号のときに横断歩道を渡るということを「信号無視」 という行為としての理解が可能なのは, 私たちが「赤信 号は止まれ, 青信号は進め」という秩序としての命題を 知っているからに他ならない. 寸なわちこの命題は,「信 号機が赤である」ときに「横断歩道を渡る」という世界 の有り様を,「信号無視」という出来事として理解するた めの背景的な基盤として作動している.

斯くして，本稿で検討しようとする対話ロボットー人 間の会話の構造は, 行為や出来事を理解するための背景 的基盤として働く規範的秩序としての構造であるがゆえ に，その数を数えるという必要性は退けられている。 こ れは Sacks [Sacks 92] が自身の講義の中で「帰納を免れ ている」 (protected against induction) と呼んだものと等し い. つまり，何かを理解し，経験するための基盤である ところの秩序は, 理解や経験に先立つ(=ア・プリオリ $)$ も の[西阪 97]であり，それ自体の有無を定量的に調べられ るようなものではない.

\section{2 なぜインタビュ一調査をしないのか}

本研究においては, 実験参加者らにインタビューをす ることで, 彼らが本当のところ何を行為していたのかと いうことを本人に確認するということはしない.これは, 本研究が採用している会話分析の, ある独特な考え方に 基づいている.

伝統的な社会学では, 行為者が何をしているのかとい うことは, 結局のところ当の本人にしかわからないとい う行為者の主観的観点から, 行為の説明がなされてきた. 一方で, 会話分析とその思想的背景であるエスノメソド ロジー (以下 EMCA) は, 社会学の領域にありながらこ の立場に与しない. むしろ EMCA では, 行為者が何を行 っているのかということは，公的に理解可能であるとい う立場をとる。本稿では，その理論的背景に深く立ち入 ることはしないが，以下の点は押さえておくと良いだろ う*3.

他者の行為が公的に理解可能であるということはつ まり，私たちは他者の行為を，基本的に理解することが できているということだ。実際に私たちは日常会話にお いて，他者が何をしているのかということを，その意図 や真意を逐一本人に問いただすことなく理解し，共同的 な日常的活動を営んでいる.しかし，だからといって私 たちは, 何の手がかりもなしに他者の行為を理解できて いるというわけではない，そこには，ある行為がまさに 当の行為であることがわかるためのプラクティス (=や り方の手続き) が, 行為理解のための仕掛けとして用意
されている，そして，行為を理解可能に組み立てるため のプラクティスは, 行為者本人がよく知っているとは限 らない。むしろプラクティスは，そのあまりの自明性ゆ えに，「見られてはいるが気づかれない (seen but unnoticed)」[Garfinkel 64] という性格を持つ.このよう なプラクティスを解明していくことこそ, 会話分析の研 究目的に他ならない.

さて，プラクティスを用いることによって他者に対し て開かれている行為の理解は, 同じ社会の成員であるわ れわれ分析者に対しても，同様に開かれているはずだ. よって私たちは, 行為者本人に対して「何をしていたの か」ということを直接尋初る必要はないだろう。しかし, 私たちは日常生活において，他者の行為を「誤解する」 ということもある. であるならば，分析者にとっても， 行為を「誤解する」可能性は，常に開かれているのでは ないだろうか. このように考えると, やはり当の行為者 本人に確認をすることが, 分析として確実であるかのよ うに思われるだろう。

分析者も当の行為を誤解する可能性については, その とおりである. しかし, 誤解の可能性があるということ によって, 行為の公的な理解可能性が損なわれるわけで はない.

このことの例証として，やはり Schegloff [Schegloff 88] の事例がわかりやすい. Schegloff は,「前置き」として用 いられる「X知ってる?」というプラクティスに注目し た。私たちは「X知ってる?」という前置きがなされた あとには，Xについての語りの本体が，前置きを産出し た話し手から語られることを期待することができる．つ まり「X知ってる?」という発話は，そのあとに語られ る sequence に先立つ pre-sequence の開始部を組織する発 話となっている. Schegloff が挙げているのは次のような 事例である.

$$
\begin{aligned}
& \text { 母親 : 明日のミーティングに誰が来るか知ってる? } \\
& \text { 息子 : 誰? } \\
& \text { 母親 : いや, 私知らないの } \\
& \text { 息子 : ああ, 多分マックオーウェンさんと(以下略) }
\end{aligned}
$$

[著者訳]

さて, 1 行目の母親の発話は, 「X 知ってる?」という 形式によって構成されていることから, pre-sequence $の$ 開 始部としての「前置き」という行為として理解すること ができる．実際に息子もこの発話を「前置き」として理 解していることが, 次の息子自身の発話からわかるだろ う。息子は「誰?」と母親の語りの続きを促すことで, 母親の発話を, 「明日のミーティングに誰が来るのか」と いうことを聞く文字通りの情報要求の質問としては聞い

\footnotetext{
${ }^{*} 3 \mathrm{EMCA}$ における行為の公的な観察可能性, 報告可能性の詳 述については, 西阪の著作[西阪 08]を参照のこと.
} 
ていないことを, 自らの発話を通じて明らかにしている.

しかし 3 行目の母親の発話から見て取れるように, 1 行目の発話は pre-sequence $の$ 開始部を組織する「前置き」 という行為ではなく，まさに「明日のミーティングに誰 が来るのか」という文字通りの情報を要求する質問であ つたことがわかる，つまり息子は，先の母親の意図を誤 解していたことになる.

この事例は結局のところ「前置き」の事例ではなかっ た.しかし，そうであっても，母親の 1 行目の発話を「前 置き」という行為として一般的に理解可能である, とい う分析も，母親の意図を誤解しているゆえに間違ってい る, というわけではない.むしろ 1 行目は,「前置き」と して理解可能だからこそ，母親の意図とは無関係に，息 子は誤解することができているし，また母親自身もこの 誤解が見当外れのものではなく, (奇妙な言い方に聞こえ るかもしれないが)合理的な誤解であることを理解して いる*4.

本稿での分析対象も，このような合理的誤解に開かれ た水準における「行為」である。すなわち，同じ社会の 成員であれば，誰に亡うても合理的に理解されうう行為 という水準における相互行為実践が，本稿において明ら かにしたい対象であり，行為者本人だけが近づきうる私 的な思い等を, 分析の対象としているわけではない.よ って本研究においては, インタビュー調査等によって行 為者本人に確認するということはしていない. もちろん, 行為者本人の意図や真意が問題となる研究課題に対して は, 会話分析ではなくインタビュー調査が, そのアプロ 一チとしてふさわしいだろう。しかし，本稿で分析対象 としている相互行為実践は, インタビュー調査によって 明らかになるような課題ではないし，また，もしインタ ビュー調査によって得られた行為者本人の主観的観点を 特権的に扱うならば, 行為の公的な理解可能性という性 格は, 却って取りこぼされる恐れすらある.このことは, 先の「前置き」の事例を振り返ってみればわかりやすい. 母親にインタビューすることにより，母親の発話を「明 日のミーティングに誰が来るのか」という文字通りの質 問として検討を終えてしまえば, 母親の発話が「前置き」 という行為として一般的に理解可能なこと, 更には, そ の理解可能性ゆえに, 息子の誤解は合理的に可能であう たという観点が見過ごされてしまうことだろう。

\section{3 本研究における主張の証拠立て}

本節ではこれまで，本研究において定量的な検討とイ ンタビュー調査をしない本研究における研究方針とその 理由を述べてきた。それでは，本稿が明らかにしようと

\footnotetext{
*4この事例において母親は，自身の質問を息子が誤解したこ とを通常のものとして扱っている。つまり母親は，「私が質問 しているのだから，私が知っているわけはないでしょう」など と, 息子の「誰?」という発話を非合理的なものとして扱って はいないことがわかる。
}

する対話ロボットー人間の会話に特有の会話構造と, その 構造の中で達成されている実験参加者らの行為や, 彼ら 自身の理解や経験の仕方は，どのようにして根拠付けら れるのだろうか.

会話分析において，主張の根拠付けのために試みられ ているのは，一つの会話断片を丹念に分析していくこと である. 特に, 逸脱例 (deviant case) の分析をすることで, 主張の根拠が明確になるということが多々ある.

Schegloff [Schegloff 93] が挙げているのは, 次のような例 だ.

先述の発話の順番交替の規則のうちに，現在の話者が 次の話者を選択するというものがある。しかし，実際の 会話を観察してみると, 現話者によって次話者が選択さ れたにもかかわらず，他の参与者が発話順番を取得する ということがままある。しかし，このような事例を単な る逸脱例として扱うのではなく，その会話を詳細に分析 してみると, 次話者として選択されていない人が「ちょ つとすみません」等の, 会話に割り込むことへの謝罪を してから話し始めるということがよくあることに気がつ く、つまり, 次話者として選択されていないにもかかわ らず，次の順番を取得するという事例は，先の順番交替 の規則が見いだせない事例ではなく，むしろ，会話の参 与者ら自身が順番交替の規則に強く志向していることを 根拠付ける事例であることがわかる.

以上のように, 会話の断片を詳細に分析してみると, 私たちにとって馴染み深いものでありながら，その自明 性ゆえにこれまで気がつかなかった多くの事柄を見出す ことができる。

\section{4. データの説明}

本稿では(株)ホンダ・リサーチ・インスティチュート・ ジャパンが収集した「マルチモーダル多人数ロボット対 話コーパス」 [Funakoshi 18] のうち，2016 年度収録のデ 一タ(以降, 本データ)を分析対象とする. 本データでは,

「20の扉ゲーム」というクイズゲームの簡略版*5を実験 参加者三人に協力しながら行ってもらった。「20の扉ゲ 一ム」は, 出題者が一つ選んだ対象概念(例えばみかん)を, Yes/No 質問を繰り返して特定していくというゲームで ある。本データでは，対話システムが自動制御する対話 ロボット（Aldebaran 製 NAO）が出題者となる.

\section{1 実験}

本データは知人三人が集まった 30 グループ(全 90 名) を対象とした対話ロボットとの対話データセットのうち の一部である. 実験参加者らは, 20 歳代から 60 歳代の

\footnotetext{
*5 本来はカテゴリカルな質問を繰り返して対象を特定するゲ 一ムであるが，ここでは時折ロボットが出すヒントを元に直接 解答を当てるゲームになっている。
} 
男女であり，その関係性は，家族，友人，同級生，職場 の知り合い等，多岐にわたる. 各グループは同じ対話口 ボット NAO を相手に, 約 25 分の「20 の扉ゲーム」を二 回行った。一回目は NAO がオペレータによって操作さ れていることが，二回目は NAO が全自動によって動作 していることが，事前に実験参加者らによって伝えられ ている. 本データは，このうちの二回目のゲームとなる 全自動の対話ロボットとの対話データである.

実験参加者らへは，トランシーバーを通じて，部屋の 外にいる実験監督者から指示が出された. 実験監督者か らの主な指示は, NAO と一緒に「遊ぶ」(ゲームに参加 する), NAO が他の実験参加者と遊んでいるのを「見て いるだけ」NAOにゲームに誘われても「素通り」する, 左右の待機スペースに「戻る」（ゲームから離脱する）の 4 種類である. これらの指示に従って実験参加者らは NAO とのゲームに従事するが, 実験監督者の指示によっ てそれぞれの実験参加者は, 実験の進行に従って入れ替 わることになる. 実験の開始直後は, NAO と一人の実験 参加者との一対一会話であるが, 実験の終了直前には, $\mathrm{NAO}$ と三人の実験参加者らによる多人数会話となる.

\section{5. 分析}

本章からは，実際の対話ロボットと人との具体的な会 話データに対して，分析を施していく.

会話分析の手法にあたってまず重要になるのは, トラ ンスクリプトと呼ばれる当該の会話の詳細な書き起こし データである.このトランスクリプトにおいては, 実際 の会話上でのやり取りを, 0.1 秒単位の沈然, 呼気, 吸気, 発話の重なりのタイミング, 発話の強弱, 発話の音調, 音の引き伸ばし等までが，微細に書き起こされる．これ ら書き起こしは, 会話分析においてよく用いられている 記号によってトランスクリプトに反映されている. デー 夕の記号の詳しい説明は，付録として本稿の最後に添え てある，書き起こされたトランスクリプトと，実際の動 画データを幾度も見直して, 会話の参与者らが従事して いる相互行為実践を明らかにしていくことが，基本的な 会話分析のアプローチである.

\section{1 分析の前提としての IRE 連鎖}

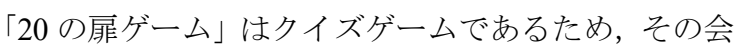
話構造は「質問の開始」 (Initiation) -「応答」 (Reply) 「評価」 (Evaluation) という，いわゆる IRE 連鎖構造 [Mehan 79] となる.

しかし, 本データ中に, IRE 連鎖の最後の要素である

「評価」を, NAO が産出しないという事例が，多数見つ かった.このとき実験参加者らは, NAO からの評価の不 在を「トラブル」として扱い，いくつかの対処を試みて いた. しかし，これらトラブルへの対処のやり方を検討 したところ, 人一人間の会話には見られない, 対話ロボッ 卜一人間の対話に特有の会話構造が観察された.
本稿では,「評価」が対話ロボットから産出されなかっ た場面に注目し, 実験参加者らによる, NAO の評価の不 在への理解が, 対話ロボットに特有の事情を考慮して達 成されていることを明らかにする.

\section{2 解答の繰り返し}

$\lceil 20$ の扉ゲーム」において, 実験参加者らの解答に対 し，IRE 連鎖構造の一要素である「評価」が NAO から 産出されないことは，対処されるべき「トラブル」とし て実験参加者らに理解されてよい, 更に, 実験参加者ら が評価の不在をどのようなトラブルとして理解している のかは, 彼らのトラブルへの対処のやり方を観察するこ とで明らかになる. NAO からの評価が不在のとき, 実験 参加者らが行う最も一般的なトラブルへの対処は, 先の 解答の「繰り返し」である. 次の断片を見てみよう.03 行目にてNAO から質問の開始 (Initiation) がなされて いる.

\section{断片（1）実験参加者 $\times 1$}

\begin{tabular}{|lll|}
\hline 01 & NAO & よし. じゃあ始めよう \\
02 & & $(0.6)$ \\
$03 \rightarrow$ & NAO(Init) & 何を考えているでしょう个か \\
04 & & $(0.7)$ \\
05 & NAO & それは丸いんだよ \\
06 & & $(0.5)$ \\
07 & B & まるい \\
08 & NAO & ヒントだよ 冬といえば \\
09 & & これだよね \\
10 & & $(0.4)$ \\
11 & B & ふゆといえばあ \\
12 & & $(0.6)$ \\
$13 \rightarrow$ & B(Reply) & それは:みかんですか \\
14 & & $(3.8)$ \\
$15 \rightarrow$ & B(Reply) & それは:みかんですか \\
16 & & $(4.9)$ \\
$17 \rightarrow$ & B(Reply) & それは: : <みかん> \\
18 & & で [すか \\
19 & NAO & [さあ 答えをどうぞ \\
\hline
\end{tabular}

実験参加者 B は, NAO からの質問の開始 (Initiation) に対して, 13 行目にて「みかん」と解答し, 続く 15 行 目，17行目で，同じ解答「みかん」を，「それは〜です か?」という表現もそのままに繰り返しているのがわ かる，それぞれの解答の次の発話順番 (14, 16 行目) は, IRE 連鎖上, NAO からの肯定もしくは否定の評価 (Evaluation) が期待できる会話上の位置となっている が, 実際には評価は産出されていない, そのためBは, 計 2 回「みかん」という解答を, 同じ表現形式にて繰り 返している. 
以上が本断片の概要となるが，先にも述べたように， 実験参加者が NAO からの評価の不在をどのようなトラ ブルとして理解していたのかは，解答を繰り返すという トラブルへの対処そのものを通じて，実験参加者自らが 明らかにしている. 人一人間の会話, 特に本断片のクイズ 形式のように対話者らが互いの発話に志向していること が前提の状況であれば，本来産出されるべき応答が不在 であるとき，その不在は直前の発話に対する「非同意」 の前触れとして理解されてよい [Pomerantz 84] .もし, 本断片における NAO からの評価の不在を, 実験参加者 らが「非同意」の前触れとして理解したのであれば，実 験参加者らが次に行うことは, 先の解答とは別の解答を することだっただろう。しかし，実験参加者 Bの「みか ん」という解答の繰り返しからは, B 自身が NAO から の評価の不在を，少なくとも「非同意」の前触れとして は理解していないことがわかる，むしろ解答をまさに繰 り返しているという事実から明らかなのは，Bが「13 行 目の発話全体が NAO に入力されていなかった」と理解 しているということである*6.

ところで，この「繰り返し」という現象が，人一人間の 会話では全く観察されないのかというと, 決してそうで はない. 本断片とよく似た現象が, 難聴者一健聴者間の会 話においても観察されている. 秋谷 [秋谷 11] は, 健聴 者が, 難聴者からの応答の不在に対して, 発話をやり直 すという場面に着目し, 難聴者の応答の不在としてそこ に現れた沈黙を，健聴者が「聴能に関係した沈黙」とし て扱っていると分析している，同様に，本断片における $\mathrm{NAO}$ の沈黙も, NAO の聴能とも言える音声認識能力に 関係した沈黙として実験参加者 Bには理解されているだ ろう.

しかしながら, 実験参加者らは, 何故 NAO に音声が 入力されていないことを理解することができたのだろう か. B の最初の解答である 13 行目の発話は, 環境音な どによって音が損なわれていることもなく，また，言い よどみや, 声の掠れなどもない, クリアな発声にて発話 されている. 更に, 発話の文頭に「それは」が置かれる ことで, 次に解答の本体が産出されることが期待できる よう組織されている。言い換えれば, 13 行目の発話は, 受け手が聞き損なう可能性をできるだけ排除するように デザインされている. また, 聞き損ないの可能性の排除 は, 実験参加者の発話デザインによってのみ達成されて

\footnotetext{
*6 対話ロボットが必ず肯定か否定の評価を返すということ を, 実験参加者らがあらかじめ知っているのであれば, NAO から評価が産出されないときに音声が入力されていないことを 疑うということは至極当然に思えるかもしれない。 しかし実際 には, 実験参加者らは, NAO とのやり取りに慣れていない実 験の初期段階においても，しばしば「繰り返し」を行う。ま た，例え NAO が必ず評価を返すということを知っていたとし ても，人一人間の対話と比較すると, 評価の不在を $\mathrm{NAO}$ の音 声入力の問題として理解することは, 決して当たり前ではな
}

いるわけではない. クイズゲームという活動において, 質問者が解答者の発話を聞き損なうという事態は，非難 の対象ともなりうるだろう。つまりクイズゲームという 活動それ自体が，質問者が解答を聞き損なうことのない ような環境を与えていると言える.

以上のように，少なくとも人一人間の会話であれば,

(受け手が難聴者でない限り) クイズゲームにおける解 答を，質問者が聞き損なっていたという理解は非合理的 である、にもかかわらず，ここでの評価の不在を，NAO が解答を聞いていたことを前提とした「非同意の前触れ」 等ではなく，「NAOに音声が入力されていない」という トラブルとして実験参加者 Bが理解できているという事 実は，私たちが対話ロボットと会話する際に考慮してい る対話ロボットに特有のある事情を思い起こさせてくれ る.

私たちは, 対話ロボットの音声認識能力に関する, あ る知識を身に着けている。つまり, 対話ロボットの音声 認識能力は完璧ではなく, ユーザの発話に何ら問題がな いにもかかわらず音声が入力されないことがある，とい うことを，実は，私たちは良く知っている．このような 対話ロボットに特有の音声認識能力に関する知識を参照 することによって, NAO の評価の不在は, クイズゲーム という活動の従事者である NAO が発話を聞き損なった という「相互行為上でのトラブル」なのではなく, 対話 ロボットであるところの NAO に音声が入力されていな い「対話の相手が機械であるがゆえのトラブル」として 理解可能となり, 更にこの理解は, NAO とのクイズゲー ムにおける, 解答の「繰り返し」という会話の構造とし て具体化している.

さて，本節においてもう一点，特に考察を深めておき たいことがある。それは，トラブルを対話ロボットの音 声認識能力が完璧でないことを考慮して理解することは, トラブルを対話ロボットに帰属されるものとして扱うこ ととは異なる，という点である。したがって，本断片に おける「NAOに音声が入力されていない」というトラブ ルが，NAO の音声認識能力に関する知識を参照して理 解されるからといって, NAO に問題があるトラブルと して理解されるわけではない.この,「対話ロボットの音 声認識能力に関する知識」と，「トラブル」との関係を明 確にするために, 本断片の「繰り返し」にもう一度着目 したい.

本断片における繰り返しのやり方には，ある諸特徴が

い. 人-人間の対話であれば, クイズの出題者が肯定/否定のど ちらの評価も下さないとき, そこに生じる沈黙は, 評価の遅延 として理解されるだろう。更にこの遅延は, 当の解答が肯定と も否定とも言えないような, いわば「惜しい」答えであったと いう理解可能性と結び付けられるかもしれない. しかし, 本断 片においては, このような可能性が破棄されているというとこ ろに，対話ロボットー人間に特有の会話の構造が見て取れる. 
観察できる。それは，一つには，繰り返しの際に，「それ は〜ですか」という表現が使用され続けているという点 である。つまり実験参加者 B は， NAO に音声が入力さ れない原因として「それは〜ですか」という表現，もし くは文法の使用そのものには, 問題を見出してはいない. その他の特徵としては, 15 行目の最初の繰り返しでは, 発話の文頭に若干の強勢が付けられているという点が挙 げられる．また，17行目の「それは：：<みかん>です か」という発話は,「それは」の語尾が引き伸ばされ，ま た,「みかん」という解答本体が若干ゆっくりと発話され ている.これらのことから, 実験参加者 B はトラブルを,

NAO が理解できない表現や文法を用いていることでは なく, 発声の強弱や速度など, 自身の発話を構成するマ テリアル (=材料) に帰属していることがわかる.

しかし，本断片の発話を自然に聞くならば，13行目の 発話は 15 行目にて強勢がおかれるほど不明瞭に聞こえ るわけではない. また, 13 行目, 15 行目の発話はとも に, 17 行目にてゆっくりと発話し直さなければならない ほど，速いわけでもない，つまり，これらの発話は，私 たちの日常会話の経験と照らし合わせて, 聞き取りに困 難さを覚えるような発声がなされているわけではない. これらの事実から, 実験参加者 B が, 人一人間の会話に おいてはトラブルとは認められないような発声の強弱や 速度といった発話のマテリアルを, 対話ロボットー人間の 会話においては，トラブルになりうるものとして理解し ていることがわかる.

以上の分析から，「対話ロボットの音声認識能力に関 する知識」と,「トラブル」との関係について, 次のこと が言えるだろう。私たちは対話ロボットの音声認識能力 が完璧ではないことを知っている. しかし, そうであっ たとしても，対話ロボットが応答をしないときに，その トラブルの原因として突き止められるものが, 常に対話 ロボットの側にあるわけではない. むしろ, 対話ロボッ トの音声認識能力の不完全さを考慮することによって, 人一人閒の会話においては不明瞭にも速くも聞こえない 自身の発話が, 対話ロボットにとうては「不明瞭」で「速 い」発話であり, 対話ロボットが応答を返さない原因で ある, という実験参加者らにとっての理解が可能となっ ている。

\subsection{NAO からの評価の不在への言及}

5.2 節にて観察したように, NAO から IRE 連鎖の最 後の要素である「評価」（Evaluation）が産出されないと き, 実験参加者らによって先の解答が繰り返されること がある. しかし, 解答の繰り返しは, NAO への音声入力 の成功を保証するものではない. 実験参加者らが解答を 繰り返しているにもかかわらず, その解答が NAO に入 力されないという状況は, 往々にして生じうる.

解答の繰り返しの後, 依然として NAO から評価が産 出されないとき, 実験参加者らは, 評価の不在に言及す
ることがある．実際に事例を見てみよう．以下の断片で は, 実験参加者らは解答を繰り返した後,「反応しない」,

「固まっちやったね」と, NAO からの評価の不在につい て言及している。

\section{断片（2）実験参加者 $\times 1$}

\begin{tabular}{|c|c|c|}
\hline 01 & NAO & どうか なな \\
\hline 02 & & $(0.8)$ \\
\hline 03 & $\mathrm{~A}$ & 答えは馬ですへか \\
\hline 04 & & $(3.5)$ \\
\hline 05 & A & う：：：ん 答えは馬 \\
\hline 06 & & $(3.2)$ \\
\hline $07 \rightarrow$ & A & `反応しない゚ \\
\hline 08 & NAO & どうかな \\
\hline
\end{tabular}

\section{断片（3）実験参加者 $\times 2$}

\begin{tabular}{|c|c|c|}
\hline 01 & C: & 象ですヤか それは象ですヤか \\
\hline 02 & & $(5.2)$ \\
\hline 03 & C: (Reply) & ＜それは象ですヤか＞ \\
\hline 04 & & $(3.6)$ \\
\hline 05 & B: (Reply) & 象ですヤか \\
\hline 06 & & $(2.2)$ \\
\hline 07 & C: (Reply) & ぞう \\
\hline 08 & & $(1.9)$ \\
\hline 09 & C: (Reply) & 象 \\
\hline 10 & & $(7.0)$ \\
\hline $11 \rightarrow$ & $\mathrm{C}:$ (Comme) & )固まっちやっ [たね \\
\hline 12 & B: & [ ( hhh $)$ 固まっ \\
\hline 13 & & $(て る)(\mathrm{hh}) \cdot \mathrm{h}$ \\
\hline 14 & $\mathrm{C}:$ & えらいね 个かんがえてるんだね \\
\hline
\end{tabular}

断片(2)では, 実験参加者 A が「馬」という解答を繰り 返した（05 行目）後に, 「反応しない」（07行目）と, 断 片(3)では, 実験参加者 C が「象」という解答を繰り返し た後に，「固まっちやったね」（11行目）と，それぞれの 断片にて実験参加者らが, 評価の不在に言及しているの が観察できるだろう。

以上のように，それぞれの断片にて実験参加者らは， 評価の不在に言及しているが，これは実験参加者らが， 今, 目の前で起こっていることを単に言い表していると いうことではない. 実際, 実験参加者らは, どのような ことでも言及するわけではない. 例えば, NAO から評価 が問題なく産出されているときに, 実験参加者らが「反 応している」,「固まってない」と言及するような事例は, 本データ中では観察されなかった．これは，本データ中 には偶々そのような事例が見つからなかった，というこ とでもないように思われる。 もし実験参加者らが，適切 に評価を産出する NAO に対して, いちいち「反応して 
いる」，「固まってない」などと言及するならば，それは 圥長で不自然な発話として聞こえるだろう。NAO から の評価の不在は，本来 NAO が産出するべき評価がない というトラブルとして理解可能であり，本来在るべきも のがないとき, そのことは会話の参与者らによって言及 されてよい. 一方で, 在るべきものが当たり前に在ると きに，会話の参与者は，そのことにいちいち言及したり はしない，もし，すべての在るものに言及しなければな らないのであれば，それはフレーム問題（frame problem) [McCarthy 69] にも通じる, 無限の言及に陥 ってしまうだろう。

NAO の評価の不在に言及することが単に目の前のも のを言い表しているのでないのだとしたら，実験参加者 らは何をしていることになるのだろうか. まずはじめの 観察として, 「反応しない」,「固まっちやったね」という 言及は，その直前の沈默の理由説明となっていることが わかる. 断片(2)の 6 行目と, 断片(3)の 10 行目の沈默は, それぞれ NAO が評価を産出することが期待できる会話 上の位置であるが，評価が産出されなかったために沈黙 が訪れている. 実験参加者らは, この沈黙の理由として, $\mathrm{NAO}$ が「反応しない」こと,「固まっちゃった」ことを 提示し, 沈黙を NAOに帰属されるものとして扱ってい る.

次に,「反応しない」,「固まっちゃったね」という表 現にて示されていることが, 対話ロボット, もしくはコ ンピュータに特有のトラブルの諸特徴として, 一般的に 理解可能であることにも注目したい．私たちはしばし ば，コンピュータが入力を受け付けないときに，このよ うな表現を用いる。とはいえ,「反応しない」,「固まっ ちやったね」という表現が用いられていること自体が, 本断片における対話ロボットー人間に特有の会話構造の 特徴であるわけではない。これらの表現は, 対話相手が 人であったとしても使用されることはあるだろう。本節 の分析においてより重要なのは, 実験参加者らが,

NAO からの評価の不在によって生じた沈黙の理由説明 として, 対話ロボットやコンピュータに特有のトラブル の諸特徴を語ることで, NAO からの評価の不在を, 他 ならぬ NAO が原因のトラブルとして扱っている，とい うことだ.

先の 5.2 節では, 評価の不在というトラブルの原因は, 必ずしも NAO に帰属されるものではなかった。対話口 ボットは, 日常会話においては特に問題なく聞き取るこ とができるユーザの発話を, 時折, 認識しないことがあ る.それは発声の大きさ, 速さ, 明瞭さの問題だったか もしれないし，もしくは，たまたま一時的に認識しなか っただけかもしれない. だからこそ実験参加者は, 次は 認識されるという期待のもとに解答を繰り返す.しかし, 解答を繰り返しても, 依然として NAO が音声を認識し ないのであれば, 次に, NAO の方に, そもそもの問題が あったという可能性が疑われるだろう.
ところで，通常の人一人間の会話において，発話上の トラブルは，そのトラブル源の産出者, つまり, トラブ ルの原因の帰属先である会話の参与者自身によって, 修 復の操作がなされることが優先的である [Schegloff 77] . つまり, トラブル源の修復の操作は, 多くの場 合，トラブル源の産出者自身によって修復されるし，も しトラブル源の産出者から修復の操作がなされなかった ときには, 聞き手がトラブル源の産出者に修復の操作を 促すことがある.

一方，本断片における評価の不在というトラブル は，発話上におけるトラブルではないものの，帰属先で ある NAO に対して, 実験参加者らから,「どうした の?」などのように修復が促されてはいない.むしろ実 験参加者らが行っていることは，「反応しない,、「固ま っちやったね」とトラブルの原因を NAO に帰属するこ とで，現在どのようなトラブルが起きているのかを，自 身が適切に理解していることの主張となっている. と同 時に, NAO からの評価の不在という現在の状況を,

$\mathrm{NAO}$ が「反応しない」,「固まっちやった」という記述 のもとに理解可能な, 秩序だった出来事として正常化す ること (normalizing) [Jefferson 04] を行っている.

ここまでの分析をまとめよう。実験参加者らは, 解 答の繰り返しの後の NAO からの評価の不在に際して, $\mathrm{NAO}$ に何かしらの問題があるというトラブルの可能性 を見出し，そのトラブルを評価の不在の理由として語る ことをしている.このような実験参加者らによる，評価 の不在の理由説明は，今，何がトラブルとなっているの かを，自身が適切に理解していることの主張であると同 時に，今起きていることの正常化となっている.

もし, 解答を繰り返した後, NAO が評価を産出するこ とを待ち続けることをしたり，もしくは，ひたすら NAO が評価を産出するまで解答を繰り返し続けるのならば, そのユーザは, 対話ロボットに問題が起きている可能性 を疑えないユーザだと見なされるだろう。これは，対話 ロボットやコンピュータが，不調などにより入力を受け 付けないことがあるということを知っているか否かとい う,一般的な亡こザとして方資格に関わる問題でもある. 例えば私たちは，コンピュータがキーボードでの入力を 受け付けなくなったとき，まずはキーボードでの入力を 繰り返してみるだろう。しかし，それでも依然としてコ ンピュータに入力がなされないのであれば, そのコンピ ユータを前にして,「あれ?」と不思議に思ったり, 何が 問題なのかを思案したり，コンピュータが反応しないこ とに困り果てたり，時にはコンピュータに対して不満を 述べたりもする.このように，トラブルに対して不思議 に思うこと, 思案すること, 困ること, 不満を述べるこ とができるのは，今トラブルが起きていることを，そし て，そのトラブルがどのようなトラブルなのか（コンピ ユータが入力を受け付けない）ということを適切に理解 
できているからに他ならない，それに対して，トラブル が起きていることを理解できていないユーザは，そもそ も不思議に思ったりすることすらできないだろうし，ど のようなトラブルなのかを理解できていなければ，コン ピュータを前にして立ちすくんでしまったり，もしくは 入力がなされるまで，ひたすらキーボードを吅き続ける かもしれない.

つまり, 対話ロボットやコンピュータがトラブルを起 こしているときに, それを理解することができることは, 社会生活を当たり前に営む上で必要とされる能力の一部 分であると言える. よって, 実験参加者らは NAO から の評価の不在に適切に言及してみせることによって, 自 身が無能力なユーザではないことを明らかにしていると 言える*7.

Suchman [Suchman 87] はコピー機と人とのコミュ ニケーションを相互行為分析したうえで，コピー機が何 にアクセスできるのかということをユーザが理解するこ とは，コピー機をうまく使えるようになることの一部分 であると述べている，同様に，対話ロボットが現在どの ような状態にあるのかということを気にかけ，発話を繰 り返したり, 繰り返しを止めて対話ロボットのトラブル に言及したりすることは, 「対話ロボットをうまく使用す ることができるユーザ」であることの一部分だと考えら れるだろう。

\section{4「繰り返し」と「評価の不在への言及」との順序}

本稿がこれまでに明らかにしたのは，NAO からの評 価の不在というトラブルに対して, 実験参加者は解答の

「繰り返し」を行うということ，また解答を繰り返して も, 依然として NAO が評価を産出しないときには, 評 価の不在に言及する，ということだった．すなわち，こ の二つの評価の不在への対処のやり方は，まず「繰り返 し」を行い，それでもなお反応が得られなかったことに 対して「言及」するという点で，順序立っていると言え る.

ところが，データを観察してみると，「繰り返し」がな されていないにもかかわらず，実験参加者が評価の不在 に言及をしている場面が見つかった．本節ではこの逸脱 事例を分析することによって，冕脱事例は単に外孔值と して無視して良いような事例なのではなく，むしろ「繰 り返し」の後の「評価の不在への言及」という順序の構 造を基盤として組織されていることを示寸.

次の断片では, 実験参加者 B が 09 行目にて,「アイド ル」と解答しているが，それに対する NAO からの評価 は産出されていない，その後 B は，NAO からの評価の 不在について言及している (11行目).

\footnotetext{
*7 本稿における「無能力なユーザ」とは, いわゆる機械音痴 などを想定しているわけではないことを，改めて注記してお く、そうではなく, 本文中にもあるように, 機械が今, トラブ ルを起こしているということ自体に考えが及ばないような,
}

\section{断片（4）実験参加者 $\times 2$}

\begin{tabular}{|lll|}
\hline 01 & $\mathrm{C}:$ & ひんとをください \\
02 & & $(6.8)$ \\
03 & $\mathrm{C}:$ & ひんとがほしーな \\
04 & & $(0.6)$ \\
05 & $\mathrm{NAO}:$ & ほらほら! \\
06 & & $(0.0)$ \\
07 & $\mathrm{~B}:$ & あ、わかった \\
08 & & $(1.9)$ \\
09 & $\mathrm{~B}:$ & それはアイドルですか? \\
10 & & $(3.9)(($ 電子音)) \\
11 & $\mathrm{~B}:$ & ん、無視されるんだよなー \\
12 & & $(0.3)$ \\
13 & $\mathrm{C}:$ & $($ 笑 $)$ \\
14 & & $(0.5)$ \\
15 & $\mathrm{C}:$ & もいっかい \\
16 & & $(1.8)$ \\
17 & B : & それはアイドルですか? \\
18 & & $(4.5)$ \\
19 & B : & おかしーなー \\
\hline
\end{tabular}

本断片以前の場面では，B はいくどか NAO に対して 解答，もしくはその他の発話を産出していたが，いずれ の発話も NAO からの反応は得られていなかった. 09 行 目で B は，「それはアイドルですか?」という新たな解 答を産出しているが，この解答に対寸る評価の不在が明 らかになったあと, B は解答の「繰り返し」を行わずに,

「ん、無視されるんだよなー」(11行目)と，NAOからの 評価の不在について言及している.

最も, ここでの「無視」という表現を取り出して, 実 験参加者 B が $\mathrm{NAO}$ の評価の不在を, NAO の意図や動 機を取り込んだ擬人主義的な解釈をしている，というこ とは想定しなくてもよいだろう。このことは, 実験参加 者らが NAO に意図や動機があると信じているわけでは ないだろうという推測ではなく, 実際の会話断片の分析 から言えることである.

人一人間の対話であれば, 受け手が, 話し手の発話を無 視したことが明らかなとき，それは非難や不満を向ける 対象となりうる。また，実際に無視したことに対しての 非難や不満が産出されたときには，それらが向けられた 会話の参与者から，非難，不満の受け入れ，つまりは謝 罪か，もしくは非難，不満に対する抗議がなされること が期待できる. B の 11 行目の発話自体は，NAO を直接 の宛先としては産出されてはいないが，間接的な宛先と してNAO に不満を向けている，上分析することも可能

「社会生活を当たり前に営む能力の一部でもある, 機械がトラ ブルを起こしている可能性を疑う能力を備えていないユーザ」 を想定している。 
である。しかし，実験参加者 C は，Bの 11 行目の発話 を聞いた後に笑っており (13 行目)，その直後に「もい つかい (もう一回)」と，B に解答を繰り返すことを要求 している. その後, 17 行目にて, B はすぐさま, その要 求を受け入れ，解答を繰り返している．このことから， 11 行目の発話の後に, NAO から謝罪もしくは抗議が産 出されるだろうということを, 実験参加者らは期待して いないことがわかる.つまり, 実験参加者らは, NAOの 評価の不在を，「NAO が無視をしている」という擬人主 義的解釈として理解しているのではなく，NAO が反応 をしないという「対話の相手が機械であるがゆえのトラ ブル」を「無視」という擬人化表現を用いて言及してい ると言える。

さて，本断片において実験参加者 B は，「アイドル」 という解答を繰り返すことなく評価の不在に言及を行っ ており，よって本断片は，これまで本稿で見てきた事例 からの逸脱事例となっている。しかし，この本断片にお いて逸脱が起きているということは，私たちがこれまで に，逸脱ではない会話断片を並べてきたからわかるとい うだけではない. むしろこの逸脱は，他ならぬ実験参加 者自身らが,まさに逸脱として遂行していることである.

15 行目において実験参加者 $\mathrm{C}$ は, 解答を繰り返すこ とを $\mathrm{B}$ に要求しているが，よくよく考えると，実験参加 者 B は，すでに NAO からの評価の不在について「無視 される」と音声が入力できないことを述べており，この 要求は, 多少圥長にも見える.しかし，15行目の実験参 加者 C による「繰り返し」要求のやり方を見てみると, 「もいっかい(もう一回)」という, 非常に切り詰められた 表現を用いた，無標の形式にて産出されている.つまり $\mathrm{C}$ は, この繰り返し要求は, 当然 $\mathrm{B}$ に受け入れられるも のとして，産出していることがわかる.

「繰り返し」を要求された側である実験参加者 B $の 17$ 行目の発話にも注目したい.こちらも，B はすでに評価 の不在に言及していると考えれば，Cの「繰り返し」要 求に対して，「さっき言ったように，NAO は無視をして いるから無駄だ」などと, 何らかの抵抗や, 異議を唱え ても良いだろう。にもかかわらず，17行目にて B は「繰 り返し」の要求を，何ら問題ないものとして受け入れて いる.

以上のように，たとえ先に，「評価の不在」への言及が なされていたとしても, その後には, 実験参加者らによ って,「繰り返し」は当然のこととして要求され, 受諾さ れている. しかし, そもそも何故, 実験参加者 B は, 先 に解答を繰り返さなかったのだろうか. 解答を繰り返さ なかったことで, 結果的に, 実験参加者 $\mathrm{C}$ に繰り返しを 要求することをさせてしまっており，会話における手順

\footnotetext{
*8 勿論, ジョークであることに後で気づいて笑ったり, 思い 出して笑ったりすることは，日常会話においてよくある。しか し, そのようなときには, なぜ遅れて笑っているのかが対話者
}

が増えているという意味で，経済的ではないようにも思 える.しかし, よく事例を観察してみると, Bの逸脱は, ある目的のためになされていたことがわかる.

11 行目の実験参加者 B の「ん，無視されるんだよな 一」という発話は，「アイドルという解答が，认まここで NAO に無視された」ということに不満を表明している のでなく,「自分の発話は, いうも NAOに入力されない」 という不満であり, 同時に, 音声入力をすることへの「諦 め」にも似た自虐のジョークとして聞くことができるだ ろう. 実際に, 11 行目を聞いた実験参加者 $\mathrm{C}$ は, 繰り返 しを要求する前の 13 行目にて笑っている. Sacks [Sacks 74b] が明らかにしたように, 笑いは基本的に, その直前 の発話と結びついて聞かれうる。よって, 相手の発話が ジョークとして理解でき，それに適切に反応しようと思 うならば，そのジョークにできるだけ近接した会話上の 位置において，まずは笑うことが重要である，さもなく ば，そのジョークに対して笑う機会は失われてしまうだ ろう*8.よって, 実験参加者 $\mathrm{C}$ は, まず $\mathrm{B}$ のジョークに 笑い, その後, B が行っていない「繰り返し」を要求し ている.

このような実験参加者 $\mathrm{B}$ による自虐のジョークは,

「繰り返し」をしないことにより,「いう毛」という要素 を強めることができているだろう。実験参加者 $\mathrm{B}$ は, 解 答の「繰り返し」を放棄することで，繰り返すまでもな く自分の発話は NAO に入力されない, という自身の理 解を示し, ジョークを際立たせることをしている.

以上の分析のように, 対話ロボットに特有の事情を考 慮したトラブルへの対処のやり方である「繰り返し」と， 繰り返したが，依然として反応が得られないときに「評 価の不在について言及すること」との間には，明らかな 順序がある。しかし，本節の分析で見たように，順序が 違えられたからといって，そのことから「順序がある」 という規範的な秩序そのものが損なわれるわけではない. むしろ実験参加者らは, 逸脱事例においても, 「順序があ る」という秩序に志向しており，その秩序に違反するこ とを何かしらの行為（ジョークを際立たせること）のリ ソースとして用いていた。

\section{6. 考察: 対話ロボットに対する態度}

これまでの分析によって, 対話ロボットに特有の事情 を考慮した実験参加者らの相互行為実践と, 対話ロボッ トー人間に特有の会話構造が明らかになった. また, 対話 ロボットに特有の事情を考慮することは，ユーザとして の資格に関わる問題であることを検討した，私たちは， 対話ロボットに対して，ユーザとして取るべき正しい態

にもわかるように，今，ジョークに気がついたことや，思い出 して笑っているということが語られなければならない. 
度と正しくない態度を知っている。 そして，もし対話口 ボットに対して正しくない態度をとったときには，無能 力なユーザと見なされうる. 本稿から示唆されたユーザ として取るべき正しい態度は，およそ以下のようなもの であった。すなわち, 対話ロボットは一度の発話で正し く音声を認識できるわけではないということを知ってい ること, よって対話ロボットからの応答が不在のときに は, 対話ロボットが音声を認識していない可能性を疑え ること, 音声の入力を繰り返してもなお, 対話ロボット が音声を認識しないときには, それを対話ロボット側の トラブルとして適切に理解し説明することができること， である.

ところで，これら対話ロボットに対して取りうる態度 は, 明らかに, 対話の相手が人であることが自明の前提 のときに私たちが取りうる相互行為実践としての態度,

つまり Wittgensteinの言うところの「魂に対する態度」 ではない，本稿でこれまで分析してきた，対話ロボット に対する実験参加者らの相互行為実践を，私たちはひと まず,「対話ロボットに対する態度」と呼ぶことにしよう。

たとえ，対話相手が対話ロボットだとユーザが知って いたとしても，「対話ロボットに対する態度」をユーザが 取らずに,「魂に対する態度」を対話ロボットに対して向 けているのであれば，それは，ユーザが，その対話ロボ ットをほぼ人と同等の存在として理解しているというこ とだと捉えることを, 本稿は提案する. この提案が妥当 であるならば,「人らしさ」の新たな評価法として, 本稿 が例示したように会話分析を用いることができることに なる.

しかし，「魂に対する態度」を向けられた対話ロボット が，チューリングテストを突破したと考えることは，二 重に誤っている.

一つ目の誤りは, チューリングテストが, 人-人間の会 話, あるいは対話ロボットー人間の会話とは, ひときわ異 なる活動であるということを, 見落としている点である. チューリングテストは, 対話の相手が人か機械かを判断 する手続きである (脚注 1 参照)。一方で, 私たちにとっ て日常的に出会う他者は, 「人なのか, それとも機械なの か」という判断が，常にレリヴァントであるわけではな い. 対話の相手が人なのか機械なのかが判然としない状 況において，それを判断しなくてはならないチューリン グテストは，その設定自体が，私たちの人や対話ロボッ トとの日常的な出会い方と, 全く異なっていると言える.

二つ目の誤りは, 「魂に対寸る態度」は, 対話の相手が 「人」かそうでないかの判定のために用いられるような ものではないということだ. Wittgensteinによれば,「魂 に対する態度」は，対話相手を，その正体が人であるか 機械であるかを理性的に問うようなことなく，それが人 らしい存在であることを自明のこととして受け止めてい るときの相互行為実践であった。つまり，「魂に対する態 度」は，対話の相手が「人」であることが自明の前提の
ときに，その帰結として相互行為中に具体化する実践な のであって，人か機械なのかが判然としないチューリン グテストのような状況において,「人」であることを判定 するための根拠として用いられるものではない.

一方で, 本研究の提案とチューリングテストには, 次 のような共通性がある。すすなわち，人と，人の特性の再 現を試みた機械との相互行為を通じた評価であるという 点, そして, その評価を, 主観評定に依ることを避ける ことを目的としているという点である. しかしながら， 本稿に㧍ける主張は, 私たちが,「人」か「機械」かがわ からない対象を，どのように判定するのかという問題 [石黒 11] とは, 距離を置く.本稿が提案しているのはあ くまでも, 眼前の対話ロボットを, 私たちは「人らしい」 対象として実際に扱っているのかどうか，という実践の 水準における「人らしさ」の評価法である。そして「人 らしさ」についての評価法としての観点においては, 本 稿が提案する方法は, チューリングテストよりも，その 解像度と深度において, 優れているといえる。

\section{7. まとめと今後の展望}

本稿ではこれまで, 対話ロボットー人間の会話に特有 の会話構造を記述してきた。 また，このような会話構造 を組織する, 対話ロボットに特有の事情を考慮した対話 ロボットに対する実験参加者らの相互行為実践を，人に 対する相互行為実践である「魂に対する態度」とは区別 して，「対話ロボットに対する態度」とした。

本稿で明らかにした実験参加者らの相互行為実践は, 「対話ロボットに対する態度」のうちのごく一部にすぎ ず，本稿では分析の対象とはしなかった場面を取り上げ れば，また違った「対話ロボットに対する態度」が観察 されることだろう。

また, 本稿での分析は, 音声が入力できないために対 話ロボットが反応しないという対話ロボットー人間の会 話においては非常に初歩的（であると同時に根源的）な トラブルと，それに対する実験参加者らの相互行為実践 を分析したが，今後対話ロボットの性能がより高まるこ とで，本稿で扱ったトラブルに私たちが遭遇することは 少なくなっていくことだろう。しかしながら，本稿で例 証した対話ロボットとの会話への会話分析的アプローチ は, 対話ロボットの性能が高まったとしても，それに伴 って更に複雑化する「対話ロボットに対する態度」を分 析するにあたって有用であり続けるように思われる。

例えば，本稿では分析の対象とはしなかった事例では， 対話ロボットが「知っている」単語, つまり対話ロボッ トに事前にプログラムされている単語に, 実験参加者ら が志向している様子が観察された．また，本稿で用いた データセットではないが, WoZ 法を用いた対話実験にお いて, 対話ロボットの発話とユーザの発話が重なってし まったときには, いつもユーザの側が発話を途中で取り やめるという事例や，対話ロボットに音声を入力する際 
に，その入力には，対話ロボットに特有の事情による， 適切なタイミングがあるということを，実験参加者らが 理解している事例なども見つかっている [小室 18]. こ のような，本稿で検討した事例より更に複雑な，対話口 ボットー人間の会話に特有の会話構造を組織する「対話口 ボットに対する態度」を明らかにしていくことは, 本研 究の今後の課題であると言える.

本稿の限界はいくつかある.まずは, 対話ロボットー人 間の会話おける「魂に対する態度」の検討が不十分なこ とが挙げられるだろう. 本データ中に, 人一人間の会話と 同様の会話構造を組織する相互行為実践が全く観察され なかったというわけではない. 本データにおいて観察さ れた, 人一人間の会話と同じ構造を組織する相互行為実践 のなかで最も単純なものを挙げるならば，それは NAO から出題されたクイズに対して, 解答をすることだろう。 クイズの出題に対して解答することは, 人一人間における クイズゲームにおいても当然, 観察できることである. よって，人一人間の会話における会話構造と同じ構造は, むしろ, 非常に多く観察されたと言うべきかもしれない. しかしながら，クイズに解答することを，果たして「魂 に対する態度」と呼んでいいのかどうかという点には, 疑問が残る。

同様に，人一人間の会話における，「対話ロボットに対 する態度」の検討もまた，不十分と言えるだろう。「繰り 返し」の分析において少し触れたように, 難聴者一健聴者 間の会話においても，本稿の「繰り返し」と似た会話の 構造は観察されている. しかし, この観察から, 発話を 繰り返す健聴者は難聴者に対して「対話ロボットに対す る態度」を取っている，という結論を導くのは，明らか に誤りである.

これらの問題点に通じるのは，「魂に対する態度」と 「対話ロボットに対する態度」とを切り分ける基準が, 十分に議論し尽くされていないことにある．本稿にて一 つの基準としていたのは，対話ロボットに関する常識的 知識であるところの「対話ロボットに特有の事情」を, ユーザらが考慮しているかどうかというものであった。 しかし,「対話ロボットに特有の事情」を考慮しているか どうかという観点によって, 先の問題点が完全に解消す るかどうかは, わからない.さしあたって必要なことは,

「対話ロボットへの態度」が観察される事例を十分に分 析することで,「対話ロボットに特有の事情」とは別の分 析の観点がないかどうかを検討することだろう。こちら もまた, 本研究の今後の課題となる.

本稿でこれまで見てきた「対話ロボットに対する態度」 は非常に入り組んだものであった．特に，「繰り返し」を しないことによって，ジョークを際立たせるということ は, 私たちが当たり前にやっていることかもしれないが, まさに「見られてはいるが気づかれない」[Garfinkel 64, 再掲] 性格のものである. 改めてそれを分析の沮上にの せることは，相互行為分析を専門にしている研究者でな
ければ困難だ. 当然, より多様な様相を呈している人一人 間の会話における相互行為実践，つまり「魂に対する態 度」は, 更に複雑な構造を組織している.このような「魂 に対する態度」を対話ロボットに実装するためには，こ れまで以上に人文系と工学系の連携が必要とされるだろ う. 本稿で示した知見が, 新たな人文・工学の学際的協 働の場を創出することを望む.

\section{謝辞}

本研究は(株)ホンダ・リサーチ・インスティチュート・ ジャパン(HRI-JP)の資金提供により設置された京都大 学・HRI-JP 協調的知能共同研究講座において実施され た. 調查に協力いただいた皆様と, 2 名の查読者，また 草稿に有益なコメントをいただいた千葉大学の西阪仰氏 に，記して感謝申し上げます。

\section{$\diamond$ 参考文献 $\diamond$}

[秋谷 11] 秋谷直矩 : 難聴の会話分析:聴能学における訂正方 略と会話における修復の組織, 保健医療社会学論集, Vol. 22, No. 2, pp.45-54(2011).

[Funakoshi 18] Funakoshi, K: A multimodal multiparty human-robot dialogue corpus for real world interaction, Proceedings of the LREC 2018 Special Speech Sessions, pp.35-39(2018).

[Garfinkel 64] Garfinkel, H. 「日常活動の基盤一当り前を見 る」, 『日常性の解剖学一知之会話』, 北澤裕, 西阪仰 [編訳］，マルジュ社(1995). ="Studies of the routine grounds of everyday activities", Social Problems, Vol. 11, No. 3, pp. 225-250(1964) 再録 Garfinkel, H.: Studies in Ethnomethodology, pp.35-75, Polity(1967).

[東中 14] 東中竜一郎：チューリングテスト「合格」のシステ 么, 情報処理, 55 巻, 9 号, pp.904-904(2014).

[石黒 11] 石黒浩: アンドロイドによるトータルチューリング テストの可能性, 人工知能学会誌, 26 巻, 11 号, pp.5054(2011).

[伊藤 99] 伊藤敏彦, 峯松信明, 中川聖一 : 間投詞の働きの 分析とシステム応答生成における間投詞の利用と評価，日本 音響学会誌, 55 巻 5 号 pp.333-342(1999).

[Jefferson 04] Jefferson, G.: “'At first I thought' A normalizing device for extraordinary events", Conversation Analysis: Studies from the first generation, pp.131-167, Philadelphia: John Benjamins(2004).

[上出 16] 上出寛子, 高嶋和毅, 新井健生 : 日本語版擬人化 尺度の作成, パーソナリティ研究, 25 巻, 3 号, pp.218225(2016).

[神田 13] 神田崇行：ロボットに「人らしさ」を感じる人々 ーフィールド実験での事例-, 日本ロボット学会誌, 31 巻, 9 号, pp.860-863(2013).

[小室 18] 小室允人：対話エージェントとの会話における発 話の重なりと解消法, 人工知能学会 言語・音声理解と対話 処理研究会資料, B5 巻, 03 号, pp.24-30(2018).

[丸田 10] 丸田健 : 魂に対寸る態度 : 他者とのかかわり・自 然とのかかわり, 大阪大学大学院人間科学研究科紀要, 36 , pp.263-278(2010).

[McCarthy 69] McCarthy, J.and Hayes, P. J.:

"Somephilosophical problems from the standpoint of artificial intelligence", Machine Intelligence, Vol. 4, pp. 463-502 (1969). 
[Mehan 79] Mehan, H.: Learning Lessons: Social Organization in the Classroom, Cambridge, Mass., Harvard University Press(1979).

[西阪 97] 西阪仰：『相互行為分析という視点一文化と心の社 会学的記述』，金子書房(1997).

[西阪 01] 西阪仰：『心と行為一エスノメソドロジーの視 点』, 岩波書店(2001).

[西阪 08] 西阪仰：『分散する身体一エスノメソドロジー的相 互行為分析の展開』, 勁草書房(2008).

[Pomerantz 84] Pomerantz, A.: "Agreeing and disagreeing with assessments: Some features of preferred/dispreferred turn shapes", In Structures of Social Action: Studies in Conversation Analysis (J. Maxwell Atkinson, John Heritage, eds.), pp. 57-101, Cambridge, U.K., Cambridge University Press(1984).

[Sacks 74a] Sacks, H., Schegloff, E. A. and Jefferson, G. 「会話のための順番交替の組織一もつとも単純な体系的記 述」, 『会話分析基本論集一順番交替と修復の組織』，西阪 仰［編訳］・S. サフト［翻訳協力］，世界思想社(2010)。 $=$ "A simplest systematics for the organization of turntaking for conversation”, Language, Vol.50, No.4, pp.696735(1974).

[Sacks 74b] Sacks, H.: "An Analysis of the Course of a Joke's Telling in Conversation” In R. Bauman \& J. Sherzer (Eds.), Explorations in the Ethnography of Speaking (Studies in the Social and Cultural Foundations of Language, pp. 337-353). Cambridge: Cambridge University Press(1974).

[Sacks 92] Sacks, H.: "Lectures on Conversation“, Oxford, Basil Blackwell, vol. 1 \& 2(1992).

[Schegloff 68] Schegloff, E, A.:"Sequencing in conversational openings", American Anthropologist, Vol. 70, No. 6, pp. 1075-1095(1968)

[Schegloff 77] Schegloff, E, A. ,Jefferson, G. and Sacks, H. 「会話における修復の組織一自己訂正の優先性」, 『会話分 析基本論集一順番交替と修復の組織』，西阪仰［編訳］・S . サフト［翻訳協力］，世界思想社(2010)。＝“The preference for self- correction in the organization of repair in conversation", Language Vol.53, pp.361382(1977).

[Schegloff 88] Schegloff, E, A.: "Presequences and indirection: Applying speech act theory to ordinary conversation”, Journal of Pragmatics, Vol. 12, No. 1, pp. 55-62(1988).

[Schegloff 93] Schegloff, E, A.: "Reflections on quantification in the study of conversation", Research on Language and Social Interaction, Vol.26, No.1, pp. 99128(1993).

[Suchman 87] Suchman, L. A.:『プランと状沉的行為：人 間-機械コミュニケーションの可能性』佐伯胖・監訳：産業 図書 (1999)= "Plans and Situated Actions": The problem of human-machine communication, Cambridge University Press(1987).

[坂本 07] 坂本大介, 神田崇行, 小野哲雄, 石黒浩, 萩田紀 博：遠隔存在感メディアとしてのアンドロイド・ロボットの 可能性，情報処理学会論文誌，Vol.48, No.12, pp.3729$3738(2007)$

[志和 09] 志和敏之, 神田崇行, 今井倫太, 石黒浩, 萩田紀 博, 安西祐一郎 : 対話ロボットの反応時間と反応遅延時にお ける間投詞の効果, 日本ロボット学会誌, 27 巻, 1 号, pp.87-95(2009).

[角森 20] 角森唯子, 東中竜一郎, 高橋哲朗, 稲葉通将 : 対 話破綻検出チャレンジ 3 における対話破綻検出の評価尺度の 選定, 人工知能学会論文誌, 35 巻, 1 号, pp. DSI-G_1-10 (2020).

[Turing 50] Turing, A. M.: "Computing Machinary and Intelligence”, Mind, Vol.59, No236, pp.433-460 (1950).
[Wittgenstein 58] Wittgenstein, Ludwig.: 『『哲学探究』 読解』，黒崎宏[訳]，産業図書(1997)=“Philosophische Untersuchungen”, Blackwell(1958).

[山崎 11] 山崎 敬一：ソシアルロボットと社会学的研究ーエス ノグラフィー・会話分析・エスノメソドロジーー, 日本ロボ ット学会誌, 29 巻, 1 号, pp.10-13 (2011).

\section{付録:トランスクリプション記号}

以下のトランスクリプションに用いられる記号は， Jefferson の転写システムを, 日本語の会話分析のために 西阪が整理したものを参考としてある。

1. 重なり [

・発話の重なりは角括弧（[）によって示される.

・重なりの終わりが示されることもある ([]).

2. 密着 $=$

・発話が密着して産出されるときは等号（=) によって 示される.

3. 沈黙，間合い

・音声が途絶えている状態があるときは, その秒数が（） 内に示される。 また 0.2 秒以下の短い間合いは，（）内 にピリオドを打った記号（.) によって示される。

4. 音声の引き延ばし ： :

・直前の音が延ばされていることは, コロンで示される. コロンの数は引き延ばしの相対的な長さに対応している

5. 呼気音・吸気音・笑い $\mathrm{h} . \mathrm{h} \quad(\mathrm{h})$

・呼気音は，hh で示される. h の数はそれぞれの音の相 対的な長さに対応している.

・吸気音は.h で示される. h の数はそれぞれの音の相対 的な長さに対応している。

・呼気音の記号は，笑いを表すのにも用いられる，とく に笑いながら発話が産出されるとき，(h)を挟むことで示 される。

6. 音の強さ・大きさ 下線

・音の強さは下線によって示される.

7. 音の小ささ。。

・音が小さいことは，当該箇所が゚。で囲まれることに より示される。

8. 音調（イントネーション） $\downarrow \downarrow$

・音調が上がっていることは个で，音調が下がっている ことはよで示される

9. スピード $><<>$ 
・発話のスピードが目立って速くなる部分は，左開きの 不等号と右開きの不等号 $(><)$ で囲まれる.

・発話のスピードが目立って遅くなる部分は, 右開きの 不等号と左開きの不等号 $(<>)$ で囲まれる.

[担当委員：平博順]

2021 年 6 月 1 日 受理

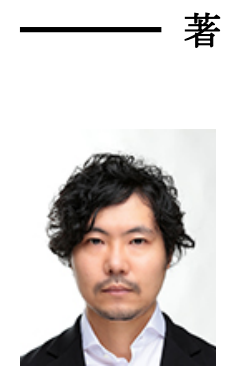

著 者紹 介

\section{小室 允人}

2013 年 3 月明治学院大学大学院社会学研究科 博士課程前期終了. 現在, 千葉大学大学院人 文社会科学研究科博士後期課程. 専門はエス ノメソドロジー, 会話分析.

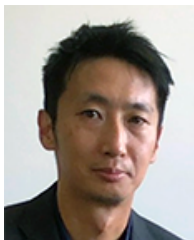

船越 孝太郎 (正会員)

2005 年東京工業大学大学院情報理工学研究 科計算工学専攻博士後期課程修了. 博士(工 学). 2006 年より (株) ホンダ・リサーチ・イ ンスティチュート・ジャパン リサーチャー. 2017 年より京都大学大学院情報学研究科知 能情報学専攻特定准教授. 2020 年より東京工 業大学科学技術創成研究院未来産業技術研究所准教授. 自然言 語処理およびマルチモーダル対話システムに関する研究に従事. 言語処理学会, 情報処理学会各会員. 